\title{
Upaya Guru dalam Meningkatkan Kemampuan Membaca Al-Qur’an pada Anak TPQ Al-Hidayah 1 Dusun Tugasari
}

\author{
H. Tasdiq ${ }^{1 *}$ dan Rezza Yuli Anjani ${ }^{2}$ \\ ${ }^{1}$ Dosen PAI STKIP Nurul Huda OKU Timur
}

\begin{abstract}
Abstrak
Penelitian ini dilatarbelakangi oleh pentingnya Al-Qur'an bagi kehidupan manusia, maka sangat diperlukan pendidikan Al-Qur'an bagi Anak-anak sebagai generasi penerus bangsa. Salah satunya pengajaran bisa dilakukan pada Taman Pendidikan Al-Qur'an. Fakta yang terjadi pada Anak TPQ Al-hidayah 1 Dusun Tugasari adalah ketika Anak membaca Al-Qur'an secara bersama-sama mereka akan kompak dan benar dalam bacaannya, akan tetapi berbeda ketika anak membaca secara individu, meskipun tidak semuanya, pada kenyataannya mereka kurang mampu membaca Al-Qur'an dengan baik dan benar dari segi makhorijul huruf ataupun dalam hukum tajwidnya. Dalam proses pendidikan di TPQ guru adalah salah satu faktor penting yang menentukan. Proses pendidikan tidak akan berhasil dengan baik tanpa adanya peran guru yang senantiasa memberikan pengajaran setiap hari pada santri-santrinya. Maka dari itu perlu adanya Upaya Guru dalam Meningkatkan Kemampuan Membaca Al-Qur'an pada Anak TPQ Al-Hidayah 1 Dusun Tugasari.

Metode penelitian yang digunakan dalam penelitian ini adalah kualitatif dengan pendekatan deskriptif. Teknik pengumpulan data dilakukan melalui wawancara, observasi dan dokumentasi. Penganalisaan data dilakukan dengan cara mereduksi data atau merangkum dari berbagai sumber yang telah tersedia, penyajian data bisa dan, uji keabsahan data, dan penarikan kesimpulan atau verifikasi.

Dari hasil penelitian diperoleh informasi upaya guru dalam meningkatkan kemampuan membaca AlQur'an pada Anak TPQ Al-Hidayah 1 Dusun Tugasari adalah interaksi yang baik ustad/ustadzah dengan santri agar santri dapat menerima pelajaran dengan mudah, memberikan pemahaman materi dengan media gambar, menghafal surat-surat pendek, mengevaluasi secara lisan dan tulisan, memperdengarkan murottal lalu santri meniru, sebelum sorogan Al-Qur'an santri harus membaca berulang-ulang minimal 3 kali, dan wajib menerapkan materi bacaan Al-Qur'an yang telah di sampaikan ustad/ustadzah, sesekali diadakan perlombaan hafalan dengan memberikan hadiah bagi santri yang bacaannya baik dan benar.
\end{abstract}

Kata kunci: Membaca Al-Qur'an, Upaya Guru, dan Taman Pendidikan Al-Qur'an.

\section{PENDAHULUAN}

Guru merupakan komponen penting yang menentukan kualitas pendidikan. Untuk itu, perlu mendapat perhatian yang lebih serius demi tercapainya tujuan sekolah yang diharapkan. Menurut Ngalim Purwanto (2000: 138), guru adalah semua orang yang pernah memberikan suatu ilmu atau kepandaian tertentu kepada seseorang atau kelompok orang. Maka untuk menjadi seorang guru harus memiliki keahlian khusus, pengetahuan, kemampuan dan di tuntut untuk dapat melaksanakan peran-perannya secara profesional yang dalam tugasnya guru tidak hanya mengajar, melatih, tetapi juga mendidik.

Guru sebagai salah satu sumber belajar berkewajiban menyediakan lingkungan belajar yang kreatif bagi kegiatan belajar peserta didik di kelas. Salah satu kegiatan yang harus guru lakukan adalah harus memiliki strategi pembelajaran yang efektif serta efisien, juga melakukan pemilihan dan penentuan metode yang sesuai sehingga menimbulkan rangsangan kepada peserta didik, karena rangsangan tersebut membawa kepada senangnya peserta didik terhadap kegiatan belajar mengajar di dalam kelas dan dapat mencapai tujuan pembelajaran yang diinginkan.

Dalam proses pendidikan di TPQ guru adalah salah satu faktor penting yang menentukan. Proses pendidikan tidak akan berhasil dengan baik tanpa adanya peran guru yang senantiasa memberikan pengajaran setiap hari pada santri-santrinya. Dalam proses pembelajaran pun peran guru masih sangat menentukan daripada metode. Peranan guru yang sangat penting ini menjadi potensi sangat besar untuk memajukan pendidikan di TPQ. Oleh karena itu guru yang baik pasti 
selalu mempersiapkan terciptanya proses pembelajaran yang baik, mulai dari pembuatan perencanaan, kemudian melaksanakan dan mengadakan evaluasi.

Menurut Surajiyo (2007:26) pengetahuan adalah hasil "tahu" manusia terhadap sesuatu atau segala perbuatan manusia untuk memahami suatu obyek yang dihadapinya. Atau hasil usaha manusia untuk memahami suatu objek tertentu. Pengetahuan merupakan sesuatu yang ada secara niscaya pada diri manusia. Keberadaannya diawali dengan kecenderungan psikis manusia sebagai bawaan kodrat manusia, yaitu dorongan ingin tahu yang bersumber dari kehendak atau kemauan (Suparlan Suhartono,2008:48). Manusia tanpa ilmu maka tidak akan mengetahui mana yang benar dan mana yang salah, oleh karena itu mencari ilmu hukumnya wajib bagi muslim laki-laki dan muslim perempuan. Sebagaimana yang terdapat dalam hadits berikut ini :

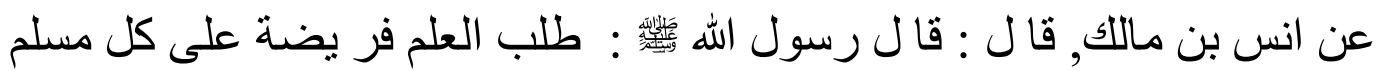

$$
\begin{aligned}
& \text { (رو اه امام ابن مجاح ) }
\end{aligned}
$$

"dari Anas bin Malik r.a, ia berkata: Rosulullah saw. Bersabda : "Mencari ilmu itu adalah kewajiban bagi setiap muslim". (HR. Imam Ibnu Majah)

Sebagai seorang muslim kita mempunyai pedoman dalam hidup kita yaitu Al-Qur'an, maka sudah merupakan kewajiban bagi setiap muslim untuk mempelajari Al-Qur'an serta diamalkan dalam kehidupan sehari-hari. Dari kecil kita sudah dididik untuk belajar membaca Al-Qur'an dalam pendidikan formal maupun non formal, baik itu di rumah, di mushola, sekolah-sekolah,Taman Pendidikan Al-Qur'an, maupun di masjid. Seperti saya lihat di Dusun Tugasari terdapat Taman Pendidikan Al-Qur'an untuk Anak-anak belajar membaca Al-Qur'an.

Menurut (Djamarah, 2008:123) Belajar Membaca Al-Qur'an sudah seharusnya dimulai sejak usia muda, yaitu masa kanak-kanak. Pada masa ini terkandung potensi yang sangat besar, sehingga para ahli pendidikan menyebutnya dengan "masa belajar (sekolah)". terutama dalam peningkatan membaca Al-qur'an haruslah dengan baik dan benar. Sebagaimana firman Allah Q.S Al-muzammil ayat 4 sebagai berikut :

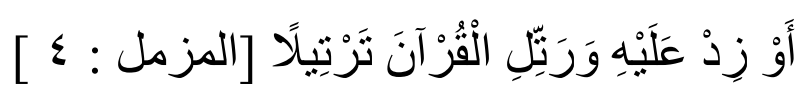

Artinya: Dan bacalah Al-Qur'an itu dengan tartil (perlahan-lahan). (Q.S.Al-muzammil : 4)

Mengingat betapa pentingnya Al-Qur'an bagi kehidupan manusia, maka sangat diperlukan pendidikan Al-Qur'an bagi Anak-anak sebagai generasi penerus bangsa. Pendidikan merupakan kegiatan seseorang atau sekelompok orang atau lembaga dalam membantu individu atau sekelompok orang untuk mencapai tujuan pendidikan. Sebelum peneliti melakukan penelitian terlebih dahulu melakukan surfei di lapangan selama satu minggu dimulai pada tanggal 10-16 maret 2018. Fakta yang terjadi pada Anak TPQ Al-hidayah 1 Dusun Tugasari adalah ketika Anak membaca AlQur'an secara bersama-sama, contohnya saja membaca surat-surat pendek maka mereka akan kompak dan benar dalam bacaannya, akan tetapi berbeda halnya ketika anak membaca secara individu, meskipun tidak semuanya pada kenyataannya mereka kurang mampu membaca Al-Qur'an dengan baik dan benar dari segi makhorijul huruf ataupun dalam hukum tajwidnya Dalam hal ini seorang guru/ustad mempunyai tanggung jawab untuk dapat mencapai tujuan pembelajaran. Karena kurang maksimalnya pembelajaran yang di peroleh anak didiknya tersebut.

Berdasarkan pemaparan di atas diketahui bahwa perlu adanya upaya-upaya yang harus dilakukan guru dalam meningkatkan kemampuan membaca Al-Qur'an, sehingga Anak mampu membacanya dengan baik dan benar sesuai dengan kaidah dan hukum tajwid, karena penanaman Al-qur'an sejak dini akan sangat baik bagi pembentukkan nilai keagamaan pada anak. Berawal dari latar belakang di atas maka peneliti akan meneliti lebih lanjut masalah tersebut dalam sebuah penelitian yang berjudul “ Upaya Guru Dalam Meningkatkan Kemampuan Membaca AI-Qur'an 


\section{Pada Anak Tpq Al-Hidayah 1 Dusun Tugasari ".}

\section{METODE/EKSPERIMEN}

Pendekatan penelitian yang digunakan dalam penelitian ini adalah pendekatan kualitatif yaitu "penelitian dengan menggunakan metode ilmiah untuk mengungkapkan suatu fenomena dengan cara mendeskripsikan data dan fakta melalui kata-kata secara menyeluruh terhadap subjek penelitian". (Mulyana, 2008:151). Sedangkan jenis penelitian yang digunakan adalah Studi Kasus yaitu strategi penelitian dimana di dalamnya peneliti menyelidiki secara cermat suatu program, peristiwa, aktivitas, proses atau sekelompok individu. Kasus-kasus dibatasi oleh waktu dan aktivitas dan peneliti mengumpulkan informasi secara lengkap dengan menggunakan berbagai prosedur pengumpulan data berdasarkan waktu yang telah ditentukan (Creswell, 2008:19).

Sumber data yang digunakan dalam penelitian ini adalah Sumber data primer dan sumber data skunder. (Sugiyono, 2010:137) Sumber data primer adalah sumber data yang langsung memberikan data kepada pengumpul data. Data primer merupakan sumber yang diperoleh langsung dari hasil wawancara yang diperoleh dari narasumber atau informan yang dianggap berpotensi dalam memberikan informasi yang relevan dan sebenarnya di lapangan. Adapun yang menjadi sumber data primer dalam penelitian ini adalah kepala Madrasah, Guru dan Santri TPQ Al-Hidayah 1 Dusun Tugasari. Sumber data skunder (Sugiyono,2010:137) adalah sumber data yang tidak langsung memberikan data kepada pengumpul data, misalnya lewat orang lain atau lewat dokumen. Dalam penelitian ini sumber data skunder yang digunakan yaitu data-data yang bersumber dari dokumentasi dan laporan-laporan tertulis yang dimiliki oleh TPQ AI-Hidayah 1 Dusun Tugasari yang berkaitan dengan Anak didik dan lembaga pendidikan.

Dalam pengecekan keabsahan data digunakan Triangulasi data yaitu teknik pemeriksaan data yang memanfaatkan sesuatu yang lain diluar data tersebut untuk keperluan pengecekan atau sebagai pembanding data tersebut (Moleong, 2007: 330). Teknik pengumpulan data, triangulasi diartikan sebagai teknik pengumpulan data yang bersifat menggabungkan dari berbagai teknik pengumpulan data dan sumber data yang telah ada. Triangulasi pada penelitian ini, peneliti gunakan sebagai pemeriksaan melalui sumber lainnya. Dalam pelaksanaannya peneliti melakukan pengecekan data yang berasal dari hasil wawancara dengan Kepala Madrasah, Guru (Ustad/ustadzah), juga Anak didik TPQ Al-Hidayah 1 Dusun Tugasari. Lebih jauh lagi, hasil wawancara tersebut kemudian peneliti telaah lagi dengan hasil pengamatan yang peneliti lakukan selama masa penelitian untuk mengetahui Upaya Guru dalam meningkatkan kualitas membaca Al-Qur'an pada Anak TPQ Al-Hidayah 1 Dusun Tugasari Setelah ketiga metode tersebut di atas terlaksana, maka data-data yang dibutuhkan akan terkumpul. Peneliti diharapkan untuk mengorganisasi dan mensistematisasi data agar siap dijadikan bahan analisis.

\section{HASIL DAN PEMBAHASAN}

\section{Kemampuan Membaca AI-Qur'an pada Anak TPQ Al-Hidayah 1 Dusun Tugasari}

Berdasarkan wawancara, observasi dan dokumentasi yang dilakukan bahwa kemampuan membaca Al-Qur'an pada Anak TPQ Al-Hidayah 1 Dusun Tugasari, sebagian sudah mampu membaca Al-Qur'an dengan baik, akan tetapi masih perlu dilakukan upaya agar mengalami peningkatan dalam membaca Al-Qur'an. Baik dari segi makhrojnya, kefasihannya, kelancaran membaca dan sesuai dengan kaidah ilmu Tajwid. 
Tabel 4.4.

\begin{tabular}{|c|c|c|c|}
\hline \multirow{2}{*}{ Jumlah } & \multicolumn{2}{|c|}{ Frekuensi } & \multirow{2}{*}{ Persent } \\
\cline { 2 - 3 } Santri & Mampu & $\begin{array}{c}\text { Belum } \\
\text { Mampu }\end{array}$ & $49 \%$ \\
\hline \multirow{2}{*}{78} & 38 & & $51 \%$ \\
\cline { 2 - 3 } & & 40 & $100 \%$ \\
\hline JUMLAH & & \\
\hline
\end{tabular}

Berdasarkan tabel tersebut, sebelum dilakukan upaya peningkatan kemampuan, dapat di ketahui Anak yang mampu membaca Al-Qur'an yakni $49 \%$ atau berjumlah 38 Anak, sedangkan Anak yang belum mampu membaca sekitar 40 Anak atau $51 \%$.

\section{Upaya Guru dalam Meningkatkan Kemampuan Membaca Al-Qur'an pada Anak TPQ Al-} Hidayah 1 Dusun Tugasari

Berdasarkan hasil penelitian di lapangan dan penjelasan dari beberapa guru dapat disimpulkan bahwa upaya guru dalam meningkatkan kemampuan membaca Al-Qur'an pada Anak TPQ beragam caranya diantaranya sebagai berikut :

a. Memberikan pemahaman hukum bacaan Al-Qur'an, pada anak usia 9 tahun kebawah dengan cara menghafal, usia 9 tahun ke atas dengan memberikan pemahaman lalu dilanjutkan dengan menghafal.

b. Lomba hafalan surat-surat pendek, yang terbaik akan diberi hadiah.

c. Memberikan pemahaman materi tajwid, jika sudah sekian pertemuan baru dilakukan evaluasi secara lisan maupun tulisan.

d. Memperdengarkan murottal Al-Qur'an kepada santri-santri, setelah itu santri mempraktikkannya.

e. Menggunakan media gambar.

f. Untuk kegiatan sorogan Al-Qur'an, menerapkan hukum bacaan Al-Qur'an yang telah dipelajari dengan wajib muraja'ah atau mengulang-ngulang bacaan minimal 3 kali.

g. Kegiatan pembelajaran dilakukan denagn sosialisasi yang baik artinya kita dapat berinteraksi bersama anak-anak dengan baik, Kegiatan pembelajaran harus bisa dinikmati oleh anakanak agar mereka dapat memahaminya dengan mudah.

Menurut penulis bahwa setelah dilakukan upaya/usaha oleh kepala dan para ustadz/ustadzah TPQ Al-Hidayah 1 Dusun Tugasari ada peningkatan dan masuk pada kategori sudah baik.

Tabel 4.5

\begin{tabular}{|c|c|c|c|}
\hline \multirow{2}{*}{$\begin{array}{c}\text { Jumlah } \\
\text { Santri }\end{array}$} & Mampu & $\begin{array}{c}\text { Belum } \\
\text { ase }\end{array}$ \\
\cline { 2 - 3 } & & & $77 \%$ \\
\hline \multirow{2}{*}{78} & 60 & 18 & $23 \%$ \\
\cline { 2 - 3 } & & & $100 \%$ \\
\hline JUMLAH & & & \\
\hline
\end{tabular}


Berdasarkan tabel tersebut, setelah dilakukan upaya maka ada peningkatan yaitu sekitar 60 Anak atau $77 \%$ sudah mampu membaca Al-Qur'an dengan baik dan benar. Sedangkan 18 Anak atau sekitar 23\% belum mampu membaca Al-Qur'an dengan baik dan benar. Jadi terdapat $28 \%$ peningkatan kemampuan membaca Al-Qur'an pada Anak TPQ Al-Hidayah 1 Dusun Tugasari.

3. Faktor pendukung dan penghambat guru dalam meningkatkan kemampuan membaca AlQur'an pada Anak TPQ Al-Hidayah 1

Berdasarkan wawancara yang dilakukan kepada kepala dan guru-guru TPQ yaitu:

a. Faktor Pendukung

1) Adanya dukungan dari keluarga (orang tua/wali santri)

2) Adanya dukungan dari masyarakat setempat

3) Dorongan diri sebagai pendidik yang bertanggung jawab terhadap anak didiknya.

4) Adanya sarana dan prasarana yang memadai.

5) Minat juga semangat dari anak-anak untuk belajar Al-Qur'an.

b. Faktor Penghambat

1) Anak kurang memperhatikan, lalai belajar, sehingga lupa muraja'ah dan hafalan pada akhirnya kurang memahami materi yang di sampaikan guru.

2) Perbedaan suku bahasa

3) Keterbatasan pengajar/guru

4) masih kurangnya kesadaran sebagai Anak/orang tua akan pentingnya membaca terlebih memahami Al-Qur'an

5) Kelas yang terbatas sehingga kegiatan mengaji kurang kondusif

6) Tingkat kemampuan berfikir santri yang berbeda-beda

\section{PENUTUP}

Berdasarkan hasil penelitian, penelitian mengenai Upaya Guru dalam Meningkatkan Kemampuan Membaca Al-Qur'an pada Anak TPQ Al-Hidayah 1 Dusun Tugasari Setelah dilakukan upaya tersebut, ternyata memang ada peningkatan kemampuan membaca Al-Qur'an pada santri. Pada awalnya $49 \%$ setelah dilakukan upaya-upaya menjadi $77 \%$. Jadi terdapat $28 \%$ peningkatan kemampuan membaca Al-Qur'an pada Anak TPQ Al-Hidayah 1 Dusun Tugasari.

\section{UCAPAN TERIMAKASIH}

Ucapan terimakasih ditujukan kepada institusi resmi atau perorangan sebagai penyandang dana, atau yang telah memberikan kontribusi lain dalam penelitian. Ucapan terimakasih dilengkapi dengan nomor surat kontrak penelitian.

\section{DAFTAR PUSTAKA}

Abdur Rahman, Mulyono. 2001. Pendidikan Bagi Anak Berkesulitan Belajar, Jakarta: Rineka Cipta, hlm. 224

Afrida, Helyati. 2012. Peran Guru PAI dalam meningkatkan prestasi belajar siswa tentang pelajaran agama di SDN Limus Nunggal 02 Cileungsi, (Jakarta:FITK Jakarta, Skripsi,), hlm.11

Ahmadi, Abu. 2007. Sosiologi Pendidikan. Jakarta : PT. Asdi Mahasatya

Alwi, Hasan.2008. Kamus Besar Bahasa Indonesia, Jakarta: Balai Pustaka.

Al-hasani, Al- Maliki, Muhammad Ibn Alawi. 2003. Samudera ilmu-ilmu Al-Qur'an. Bandung: PT Mizan Pustaka. Cet. 1

Al-utsaimin, Muhammad Ibn Shalih. 2001. Ulumul Qur'an, Jakarta: PT Raja Grafindo Persada.

Atmaka, Dri. 2004. Pengantar Pendidikan, Salatiga: Widyasari Press, hlm. 17 
Darajat, Zakiyah. 2006. IImu Pendidikan Islam, (Jakarta:Bumi Aksara), hal. 39

Departemen Agama RI, 2008. Al-Qur'an dan terjemahnya, Bandung: Diponegoro.

Djamarah, Syaiful Bahri. 2008. Psikologi Belajar, Jakarta: Rineka Cipta, Cet. Ke- 2, hlm. 123.

Drs. Hamdani, M.A. 2001. D asar-Dasar Kependidikan, Bandung: CV PUSTAKA SETIA Cetakan ke-1, hlm. 140

John W. Creswell. 2008. Research Design Pendekatan Kualitatif, Kuantitatif, dan Mixed, Edisi Ketiga Bandung : Pustaka Pelajar, hlm. 19.

Lexi J. Moleong. 2007. Metode Penelitian Kualitatif, Bandung:Remaja Rosdakarya, hlm. 330

Majid khon,Abdul. 2011. praktikum qiro'at keanehan bacaan Al-Qur'an Qiro'at Ashim dari Hafash, Jakarta:Amzah hlm. 35

Mulyana, Deddy. 2008. Metodologi Penelitian Kualitatif. Bandung: Remaja Rosdakarya, hlm. 151

Purwanto, Ngalim. 2000. Ilmu Pendidikan Teoritis dan Praktis, Bandung: Remaja Rosda karya, hlm. 138

Shihab,Quraish.2008. Sejarah \& Ulumul Qur'an Jakarta: Pustaka Firdaus. hlm. 13

R.I. Shannun, 3J.A. Battle. 2003. Gagasan Baru dalam Pendidikan, Jakarta: Mutiara, hlm. 178.

Sugiyono. 2010. Metode Penelitian Pendidikan Pendekatan Kuantitatif, Kualitatif dan R\&D (Alfabeta, Bandung)

Suhartono, Suparlan. 2008. Filsafat Pendidikan. Yogyakarta: Ar-ruzz Media.

Tim Penyusun Kamus Besar Bahasa Indonesia. 2002. Kamus Besar Indonesia, Jakarta: Balai Pustaka.

Syafi'i, A. Mas'ud. 2001. Pelajaran Tajwid (Bandung:Putra Jaya) 